\title{
The Effect of Administration of Omega-3 and Vitamin E on the Levels of Reactive Oxygen Species (ROS) and Nitric Oxide (NO) in Preeclampsia White Rats (Rattus Norvegicus)
}

\author{
Dina Taufia ${ }^{1}$, Syamel Muhammad², Arni Amir ${ }^{3}$ \\ 1,2,3 Magister Kebidanan, Fakultas Kedokteran, Universitas Andalas \\ Corresponding Author: Arni Amir
}

\begin{abstract}
Background: Preeclampsia is a disease with a variety of theories that describe the uncertainty of the pathophysiology. According to the oxidative stress theory, preeclampsia originates from the failure of trophoblast invasion during the implantation process, causing ischemia and placental hypoxia, which in turn causes cell damage, including placental endothelial cell dysfunction. Omega-3 fatty acids and vitamin E have an important role in preventing preeclampsia. Omega-3 fatty acids play an important role in maintaining cell membranes and anti-inflammatory processes. At the same time, vitamin $\mathrm{E}$ acts as a fat-soluble antioxidant that can prevent oxidative stress, inhibit proinflammatory cytokines, and protect fatty acids from oxidation. Aim: The purpose of this study was to determine the effect of omega-3 and vitamin $\mathrm{E}$ on the level of ROS and NO in pregnant rats with preeclampsia models.

Method \& Material: This type of research is experimental with Post-Test Only Control Group Design. The sample consisted of 35 pregnant rats, which were divided into five groups. On the 19th day, blood serum was taken to check the levels of ROS and NO. The measuring instrument used is a spectrophotometer with the ELISA method. Data were analyzed using the Shapiro Wilks normality test. After the parametric test was completed, the hypothesis was tested using oneway ANOVA.
\end{abstract}

Results: The average levels of ROS in each group were K- : 121,684 ng/L, K+ : 143,885 ng/L, P1 : 136,250 ng/L, P2 : 132.433 ng/L, and
P3 : 122,993 ng/L. The average levels of NO obtained were $\mathrm{K}-\mathrm{:}$ 29,502 ng/L, K+: 26,053 ng/L, P1: 27,250 ng/L, P2: 27,555 ng/L, and P3: $32,278 \mathrm{ng} / \mathrm{L}$. The results of one-way ANOVA analysis showed that the administration of omega-3 and vitamin $\mathrm{E}$ had a significant difference between the control and treatment groups, both at levels of ROS $(p=0.001)$ and levels of $\mathrm{NO}(\mathrm{p}=0.001)$.

Conclusion: The administration of omega-3, vitamin $\mathrm{E}$, and omega-3 plus vitamin $\mathrm{E}$ can reduce ROS levels in pregnant rats with preeclampsia models. There is an increase of NO levels only in the administration of omega-3 plus vitamin E.

Keywords: Omega-3, Vitamin E, Oxidative stress, ROS, NO, Preeclampsia

\section{INTRODUCTION}

Preeclampsia (PE) is a pregnancy disease that is very dangerous to the health of the mother and fetus and can develop into more severe complications (e.g., eclampsia) with long-term consequences (ACOG, 2020). Approximately 295,000 women died from complications during pregnancy and childbirth, including one of these complications was due to preeclampsia and eclampsia (WHO, 2019).

In Indonesia, maternal mortality is still dominated by three leading causes: bleeding, hypertension in pregnancy, and infection (MoH, 2015). In 2019, the most common causes of maternal death were bleeding (1,280 cases), hypertension in 
pregnancy (1,066 cases), and infection (207 cases) (Ministry of Health, 2020).

Preeclampsia (PE) is a pregnancyspecific syndrome that can affect all organ systems. PE is diagnosed after 20 weeks of gestation (Cunningham et al., 2014). Clinically, preeclampsia is characterized by systolic blood pressure > $140 \mathrm{mmHg}$, diastolic blood pressure $>90 \mathrm{mmHg}$, which was measured twice at 4-hour intervals, proteinuria in 24 hours $>300 \mathrm{mg}$, or protein/creatinine ratio $>$ 0:3 (Tenorio et al., 2019).

Starting from the disruption of spiral artery remodeling that can cause placental hypoxia, it leads to oxidative stress due to an imbalance between ROS and antioxidants, causing damage to proteins, lipids, and DNA (Shcoot et al., 2018). At the cellular level, preeclampsia has been primarily associated with the release of free radicals by the placenta and is considered a major molecular determinant of maternal disease (Aouache et al., 2018).

Oxidative stress can alter placental remodeling and vascular endothelial dysfunction of the placenta leading to ischemia/reperfusion injury with increased xanthine activity resulting in high oxidation of ROS levels (Reyes et al., 2019). Oxidative stress is relevant to the pathophysiology of preeclampsia because it induces the release of proinflammatory cytokines and chemokines in the trophoblast (Ahmad et al., 2019) and results in increased production of lipid peroxides and ROS such as superoxide (Chaiworapangsa, 2018).

The formation of lipid peroxides makes free radicals more toxic to damage endothelial cells and interfere with NO production. The endothelial relaxation process is also disrupted and hypertension (Astutik, Adriani \& Wirjatmadi, 2014). Increased ROS induction can inhibit BH4 so that the eNOS structure becomes unstable and unable to produce NO (Darwin et al., 2017). NO deficiency induces characteristic uteroplacental changes, including decreased uterine artery diameter, spiral artery length, and uteroplacental blood flow (Phipps et al., 2016).

The use of omega 3 in preeclampsia is still being studied, and the exact causal relationship has not been determined. It is necessary to conduct a study to determine the effect of omega-3 and vitamin E on ROS and NO levels in pregnant white rats (Rattus norvegicus) with preeclampsia model.

\section{LITERATURE REVIEW}

In oxidative stress conditions, antioxidants play an important role in inhibiting and neutralizing the occurrence of oxidation reactions involving free radicals (Beg et al., 2011). Antioxidant supplementation in patients with decreased antioxidant status plays an important role in reducing the incidence of hypertension in pregnancy (Tripathi et al., 2016).

As one of the fat-soluble antioxidants, Vitamin $\mathrm{E}$ is responsible for protecting cells against inflammatory responses and lipid peroxidation, which shows a regulatory effect on blood pressure and may be beneficial in preventing preeclampsia (Fu Zhu Mei et al., 2017). Vitamin E ( $\alpha$-tocopherol) is recognized as a lipophilic antioxidant that can protect lipoproteins, PUFAs, cell membranes, and intracellular from damage by counteracting free radicals (Rusiani et al., 2019). Vitamin $\mathrm{E}$ also plays an important role in inhibiting the increased production of proinflammatory cytokines or inflammation (Parwata, 2016; Lalenoh, 2018).

Apart from vitamin E, omega 3 fatty acids also play many important roles during pregnancy, especially in cardiovascular remodeling for women with hypertension (Burchakov, Kuznetsova \&Uspenskaya, 2017). The content of DHA omega-3 can reduce placental oxidative stress by increasing the levels of resolving and protecting that maintain oxidation in certain areas (Utami et al., 2018).

Omega-3, including EPA/DHA, is a metabolite precursor and a strong lipid mediator and has an important role in the body, especially in cell membranes, anti- 
inflammatory processes, and cell membrane viscosity (Smith et al., 2011). A metaanalysis by Bakoueiet al. (2020) said that omega-3 supplementation played a protective role against the risk of preeclampsia but did not reduce the risk of hypertension due to pregnancy, so it was effective in preventing the incidence of preeclampsia in women with low-risk pregnancies.

\section{MATERIALS \& METHODS}

This research is experimental research with Post-Test Only Control Group Design. The independent variables in this study were omega-3 doses (EPA/DHA: $180 \mathrm{mg} / 120 \mathrm{mg})$, vitamin $\mathrm{E}$ doses $(\alpha-$ tocopherol: $300 \mathrm{mg}$ ), which were converted to rat doses and then administered orally, while the dependent variables were ROS levels and NO levels.

The sample of this study was pregnant white rats (Rattus norvegicus) with 35 rats. The preeclampsia induction agent used was L-NAME at a dose of 50 $\mathrm{mg} / \mathrm{kg} / \mathrm{BW}$. The sample in this study was divided into five groups, namely the negative control group (K-) without treatment, the positive control group $(\mathrm{K}+)$ given L-NAME induction agent, group (P1) given L-NAME + omega-3, group (P2) given L-NAME + vitamin E, and group (P3) were given L-NAME + omega-3 + vitamin $\mathrm{E}$ given at 10-19 days of gestation. The criteria for the sample in this study were female rats with an average age of 10 weeks, an average body weight of 200 grams, and rats in good health and who did not experience an abortion or died during the study.

This research was conducted at the Animal House and Biomedical Laboratory, Faculty of Medicine, Andalas University, Padang, from August 2020-May 2021. NO examination was carried out using the Elabscience colorimetric assay kit method catalog no: E-BC-K035-M, while ROS examination was carried out using the BT LAB brand ELISA kit method, catalog no. E0900Ra. Both measuring instruments use a spectrophotometer. Data were analyzed using the Shapiro Wilks normality test. After the parametric test was carried out, it was continued with hypothesis testing using one-way ANOVA.

After obtaining permission to conduct research, this research was conducted and has been tested through an ethical test process by the research ethics committee of the Faculty of Medicine, Andalas University, Padang, with a certificate No: 241/UN.16.2/KEP-FK/2021.

\section{Statistical Analysis}

This research is experimental research with Post-Test Only Control Group Design. The independent variables in this study were omega-3 doses (EPA/DHA: $180 \mathrm{mg} / 120 \mathrm{mg})$, vitamin $\mathrm{E}$ doses $(\alpha-$ tocopherol: $300 \mathrm{mg}$ ), which were converted to rat doses and then administered orally, while the dependent variables were ROS levels and NO levels.

\section{RESULT}

\section{Tests of Normality}

The results of the data normality test on the variables of ROS and NO were normally distributed ( $\mathrm{p}>0.05 ; 0.582$ for ROS and 0.166 for NO).

\section{Hypothesis Testing}

In this study, the results obtained include the average levels of ROS and the average levels of NO.

Table 1 - Average ROS levels of white rats (Rattus norvegicus) in the control and treatment groups

\begin{tabular}{|l|l|l|}
\hline \multirow{2}{*}{ groups } & ROS Levels (ng/L) & \multirow{2}{*}{$\boldsymbol{N}$} \\
\cline { 2 - 2 } & Mean \pm SD & \\
\hline K- & $121,684 \pm 1,8880$ & \multirow{3}{*}{0,001} \\
\hline K+ & $143,885 \pm 2,7280$ & \\
\hline P1 & $136,250 \pm 2,9263$ & \\
\hline P2 & $132,433 \pm 3,5455$ & \\
\hline P3 & $122,993 \pm 3,1530$ & \\
\hline
\end{tabular}

Table 1 shows that the ROS levels in the $\mathrm{K}+$ group were higher than in the negative and treatment groups, namely $143.885 \mathrm{ng} / \mathrm{L}$. Among the three treatment groups, the P3 group had lower levels of ROS than P1 and P2, which was 122,993 $\mathrm{ng} / \mathrm{L}$. The best decrease in ROS levels 
Dina Taufia et.al. The effect of administration of omega-3 and vitamin $e$ on the levels of reactive oxygen species (ROS) and nitric oxide (NO) in preeclampsia white rats (rattus norvegicus).

occurred in group P3. Based on the OneWay ANOVA statistical test results, there was a significant difference between the control group and the treatment group in terms of ROS levels with $\mathrm{p}=0.001(\mathrm{p}$ $<0.05)$.
Further analysis to see the difference between the control and treatment groups was carried out with the Multiple Comparison Test (Pos Hoc Test) for the LSD type in table 2 as follows:

Table 2-LSD Post Hoc Test Results on Rattus Norvergicus ROS Levels in Control and Treatment Groups.

\begin{tabular}{|c|c|c|c|c|c|}
\hline Dependent variable & I (Group) & J (Group) & Sig. & \multicolumn{2}{|c|}{ 95\% confidence interval } \\
\hline & & & & Lower Bound & Upper Bound \\
\hline \multirow[t]{20}{*}{ ROS } & K- & $\mathrm{K}+$ & ,000 & $-25,651$ & $-18,752$ \\
\hline & & P1 &, 000 & $-18,016$ & $-11,117$ \\
\hline & & $\mathrm{P} 2$ &, 000 & $-14,199$ & $-7,300$ \\
\hline & & P3 & ,442 & $-4,759$ & 2,140 \\
\hline & $\mathrm{K}+$ & K- &, 000 & 18,752 & 25,651 \\
\hline & & P1 &, 000 & 4,185 & 11,804 \\
\hline & & $\mathrm{P} 2$ & ,000 & 8,002 & 14,901 \\
\hline & & P3 &, 000 & 17,442 & 24,342 \\
\hline & P1 & K- &, 000 & 11,117 & 18,016 \\
\hline & & $\mathrm{K}+$ & ,000 & $-11,084$ & $-4,185$ \\
\hline & & $\mathrm{P} 2$ & 031 & ,367 & 7,266 \\
\hline & & P3 &, 000 & 9,808 & 16,707 \\
\hline & $\mathrm{P} 2$ & K- &, 000 & 7,300 & 14,199 \\
\hline & & $\mathrm{K}+$ & ,000 & $-14,901$ & $-8,002$ \\
\hline & & P1 & ,031 & $-7,266$ &,- 367 \\
\hline & & P3 &, 000 & 5,991 & 12,890 \\
\hline & P3 & K- & ,442 & $-2,140$ & 4,759 \\
\hline & & $\mathrm{K}+$ &, 000 & $-24,342$ & $-17,442$ \\
\hline & & $\mathrm{P} 1$ & , 000 & $-16,707$ & $-9,808$ \\
\hline & & P2 & 000 & $-12,890$ & $-5,991$ \\
\hline
\end{tabular}

Table 2 shows that the administration of omega-3 and vitamin $\mathrm{E}$ on ROS levels of white rats (Rattus Norvegicus) had a significant difference between the $\mathrm{K}$ - group and $\mathrm{K}+(\mathrm{p}$ value $=$ 0.001 ), $\mathrm{K}+$ and $\mathrm{P} 1$ ( $\mathrm{p}$ value $=0.001$ ), the $\mathrm{K}+$ group with $\mathrm{P} 2$ (p value $=0.001)$, group $\mathrm{K}+$ with P3 $(p$ value $=0.001)$.

Table 3-Average NO Levels in White Rats (Rattus Norvegicus) in the Control and Treatment Groups

\begin{tabular}{|c|c|c|}
\hline \multirow[b]{2}{*}{ Groups } & NO Levels (ng/L) & \multirow[b]{2}{*}{$\boldsymbol{P}$} \\
\hline & Mean \pm SD & \\
\hline K- & $29,502 \pm 2,5047$ & \multirow{5}{*}{0,001} \\
\hline $\mathrm{K}+$ & $26,053 \pm 1,0098$ & \\
\hline $\mathrm{P} 1$ & $27,250 \pm 3,0695$ & \\
\hline $\mathrm{P} 2$ & $27,555 \pm 2,3030$ & \\
\hline P3 & $32,278 \pm 2,0791$ & \\
\hline
\end{tabular}

Table 3 shows that the NO levels in the $\mathrm{K}+$ group were lower than the negative group and the treatment group, which was $26,053 \mathrm{ng} / \mathrm{L}$. Among the three treatment groups, the P3 group had higher levels of ROS than P1 and P2, which was 32.278 ng/L. The best increase in NO levels occurred in group P3. Based on the OneWay ANOVA statistical test results, there was a significant difference between the control group and the treatment group in terms of NO levels with $p=0.001(p<0.05)$.

Further analysis to see the difference between the control group and the treatment group was carried out using the Multiple Comparison (Pos Hoc Test) LSD tests, as presented in table 4 as follows:

Table 4

\begin{tabular}{|l|l|l|l|l|l|}
\hline Dependent variable & I (Group) & J (Group) & Sig. & \multicolumn{2}{|l|}{ 95\% confidence interval } \\
\hline & & & & Lower Bound & Upper Bound \\
\hline \multirow{4}{*}{ ROS } & K- & K &, 000 &, 719 & 6,178 \\
\cline { 2 - 6 } & & P1 &, 000 &,- 478 & 4,981 \\
\cline { 2 - 6 } & & P2 &, 000 &,- 783 & 4,676 \\
\cline { 2 - 6 } & & P3 &, 442 & $-5,506$ &,- 047 \\
\cline { 2 - 6 } & K+ & K- &, 000 & $-6,178$ &,- 719 \\
\cline { 2 - 6 } & & P1 &, 000 & $-3,926$ & 1,533 \\
\cline { 2 - 6 } & & P2 &, 000 & $-4,231$ & 1,228 \\
\cline { 2 - 6 } & & P3 &, 000 & $-8,954$ & $-3,496$ \\
\hline
\end{tabular}


Dina Taufia et.al. The effect of administration of omega-3 and vitamin e on the levels of reactive oxygen species (ROS) and nitric oxide (NO) in preeclampsia white rats (rattus norvegicus).

\begin{tabular}{|l|l|l|l|l|l|}
\hline \multirow{8}{*}{} & \multicolumn{5}{|c|}{ Table 4 Continued... } \\
\cline { 2 - 6 } & P1 & K- &, 000 & $-4,981$ &, 478 \\
\cline { 2 - 6 } & & K + &, 000 & $-1,533$ & 3,926 \\
\cline { 2 - 6 } & P2 &, 031 & $-3,034$ & 2,424 \\
\cline { 2 - 6 } & P3 &, 000 & $-7,758$ & $-2,299$ \\
\cline { 2 - 6 } & P2 & K- &, 000 & $-4,676$ &, 783 \\
\cline { 2 - 6 } & K + &, 000 & $-1,228$ & 4,231 \\
\cline { 2 - 6 } & P1 &, 031 & $-2,424$ & 3,034 \\
\cline { 2 - 6 } & P3 &, 000 & $-7,453$ & $-1,994$ \\
\cline { 2 - 6 } & P3 & K- &, 442 &, 047 & 5,506 \\
\cline { 2 - 6 } & K+ &, 000 & 3,496 & 8,954 \\
\cline { 2 - 6 } & P1 &, 000 & 2,299 & 7,758 \\
\cline { 2 - 6 } & & P2 &, 000 & 1,994 & 7,453 \\
\hline
\end{tabular}

Table 4 shows that the administration of omega-3 and vitamin $\mathrm{E}$ to the NO levels of white rats (Rattus Norvegicus) had a significant difference between the $\mathrm{K}$ - group and the $\mathrm{K}+$ group (pvalue $=0.015)$, the $\mathrm{K}+$ group, and the $\mathrm{P} 3$ group $(\mathrm{p}$-value $=0.001)$.

\section{DISCUSSION}

\section{Level of ROS on Preeclampsia with Omega-3 and Vitamin E Treatment}

Results showed the positive control group had a higher average level of ROS than the negative control group. This means that the group of rats induced by hypertension had higher levels of ROS than the group of normal pregnant rats. Elevated levels of ROS have contributed to several cardiovascular diseases by causing endothelial dysfunction so that an important role of antioxidants is required in the amelioration of this pathophysiological condition (Aldosari et al., 2018).

According to Tenorio et al. (2019), the mechanism of oxidative stress in PE begins with an abnormal trophoblast invasion process that repeatedly culminates from hypoxia, increasing the production of ROS, RNS, and greater lipid peroxide and is characterized by a decrease in antioxidants. The ischemic placenta can induce ROS. In several studies, placental homogenates from PE patients showed 39\% higher hydrogen peroxide production than normal pregnant women, and under these circumstances, vitamin $\mathrm{E}$ could reduce peroxynitrite through electron supply (Matsubara et al., 2015). Studies show that antioxidants play an important role in preventing hypertension by reducing oxidative stress caused by endothelial dysfunction (Parwata, 2016).

This study found that the average value of ROS levels in the treatment group was lower than in the positive control group. The decrease in ROS levels occurred in the three treatment groups, and the best decrease was found in the group given omega-3 plus vitamin E.

Each group compared to the positive control group $(\mathrm{K}+)$ had a significant effect on ROS levels, namely in the omega-3 only (P1) group with a value ( $\mathrm{p}=0.001)$, vitamin $\mathrm{E}$ alone (P2) with a value ( $\mathrm{p}=0.001)$, and the administration of omega-3 plus vitamin $\mathrm{E}$ (P3) with a value $(\mathrm{p}=0.001)$.

In line with the research of Vijayalaksmi et al. (2013), supplementation of vitamin E, omega-3, and their combination can significantly reduce oxidative stress when compared to the group not given supplementation. Research conducted by Kemse et al. (2014) in experimental animals showed that combined supplementation of vitamin B12, folic acid, and omega-3 fatty acids was beneficial for the management of preeclampsia, especially in reducing oxidative stress. Omega-3 fatty acids are very susceptible to peroxidation because of the high number of double bonds in their structure. The combination of vitamin E with DHA will help reduce lipid peroxidation (Kasture, 2018).

The research of Kemse et al. (2016) proved that omega-3 supplementation is beneficial in reducing inflammation and increasing angiogenesis in rat models of hypertension. Further studies need to be tested on humans. Cordoso and Surve (2016), in their research on vitamin C and 
vitamin E supplementation for the prevention of preeclampsia, revealed that there was a $46 \%$ reduction in the risk of preeclampsia in the treatment group compared to the control group. Vitamin E can cross the placenta easily and has a strong antioxidant effect for several tissues making it important for early embryonic development during implantation and protection against oxidative stress damage (Abdou et al., 2017).

\section{Level of NO on Preeclampsia with Omega-3 and Vitamin E Treatment}

This study showed that the NO levels in the positive control group had lower values than the negative control group. The placenta in $\mathrm{PE}$ is associated with hypoxia/reoxygenation phenomena, fluctuations in the oxygen gradient, altered antioxidant capacity, oxidative stress, and reduced nitric oxide (NO) bioavailability (Guerby et al., 2021). Oxidative stress causes endothelial dysfunction, which causes a decrease in the release or production of NO, a proliferation of the muscle walls of blood vessels and collagen deposits, which causes thickening of the tunica media, narrowing of the blood vessel lumen, which will eventually disrupt the process of vasodilation (Magenta et al., 2014; Fosterman et al., 2014; Fosterman et al. al., 2017). Decreased NO bioavailability results from decreased NO production and/or increased ROS production leading to an imbalance between $\mathrm{NO}$ and superoxide (O2--), formation of ONOO-, and inhibition of eNOS activity (Guerby et al., 2021).

In this study, the average value of NO levels in the three treatment groups was higher than in the control group. The best NO levels were found in the group given omega-3 plus vitamin E. Each group that was compared with the positive control group $(\mathrm{K}+)$, which had a significant effect on NO levels, was in the group given omega-3 plus vitamin E (P3) only with a value of $(p=0.001)$. In line with research conducted by Sepidarkish et al. (2019) on the effect of omega-3 plus a combination of vitamin E on oxidative stress, it was found that there was a significant decrease in MDA levels and, on the contrary, increased NO and TAC levels compared to the placebo group.

Based on the Cochrane review by Middelton et al. (2018) regarding omega-3 fatty acid supplementation during pregnancy, there is some evidence of reduced risk of preeclampsia for secondary outcomes. Still, the certainty of the evidence is low, so further research is needed. In this study, the administration of vitamin $\mathrm{E}$ alone did not significantly affect NO levels in preeclampsia model rats. In line with a meta-analysis study by Basu \& Timothy (2020) on antioxidant supplementation in preeclampsia and gestational diabetes explained that clinical trials on vitamin $\mathrm{C}$ and vitamin $\mathrm{E}$ mostly showed no effect in reducing the incidence of preeclampsia in pregnant women with and without type 1 diabetes. The preliminary study (2018) concluded that omega-3 supplementation during pregnancy is good for placental and fetal development, while further research is needed for its effectiveness in preeclampsia.

There are conflicting reports of NO levels in the incidence of PE. Sutton et al. (2019) explained that in preeclampsia, nitrate/nitrite levels had been reported to be significantly lower, unchanged, or higher compared to normotensive pregnant women. This difference may be due to several factors such as food intake/diet, iron status, and treatment of kidney cleansing.

\section{CONCLUSION}

The administration of omega-3, vitamin $\mathrm{E}$, and omega-3 plus vitamin $\mathrm{E}$ reduced ROS levels of rats (Rattus norvegicus) pregnant with preeclampsia models. Meanwhile, NO levels only affected the administration of a combination of omega-3 plus vitamin E but did not affect individual administration.

\section{Acknowledgement: None}

Conflict of Interest: None 


\section{Source of Funding: None}

\section{Ethical Approval: Approved}

\section{REFERENCES}

1. American College of Obstetricians and Gynecologists Committee on Practice Bulletins- Obstetrics. Gestational hypertension and preeclampsia: Acog practice bulletin, number 222. Obstet. Gynecol.2020; (135);e237-e260.

2. WHO.MaternalMortality. 2019. www.who.int/gho/maternal_health/mortali ty/maternal_mortality_text.2019.

(Diakses 15 September 2020).

3. Kementrian Kesehatan RI. Profil Kesehatan Indonesia Tahun 2014. Jakarta : Kementerian Kesehatan Republik Indonesia. 2015;97-99.

4. Kementrian Kesehatan RI. Profil Kesehatan Indonesia Tahun 2019. Jakarta : Kementerian Kesehatan Republik Indonesia. 2020; 85-87.

5. Cunningham, F.G. Leveno, K.J. Bloom, S.L. Spong, C.Y. Dashe, J.S , Hoffman, B.L. et al. William Obstetrics. 24th ed. Vol.2 New York : Mc Graw Hill. 2014; 396-404.

6. Tenerio, M.B. Ferreira, R.C. Moura, F.A. Bueno, M.B. Olievera, A.C.M .\& Goulart, M.O.V. Cross-Talk Between Oxidative Stress and Inflammation in Preeclampsia. Brazil :Universidade Federal de Alagoas. 2019;1-27. https://doi.org/10.1155/2019/8238727

7. Schoots, S.J. Gordijn, S.A. Scherjon, H. van Goor, J.L \&Hillebrands. Oxidative stress in placental pathology, Placenta 69. 2018; 153-161. https://doi.org/ 10.1016/j.placenta.2018.03.00

8. Reyes, S.S.J. Olivan , M.M.G. Flores, H.I \& Garcia, O. D. Oxidative Stress in Pregnancy Complicated by Preeclampsia. Mexico : Archives of Biochemistry and Biophysic . 2019. https://doi.org/10.1016/j.abb.2020.108255

9. Ahmad, I., Zimmerman, M., and Moore, T. Oxidative Stress in Early Pregnancy and the Risk of Preeclampsia. Pregnancy Hypertensy. 2019;99-102.
10. Aouache, R., Biquard, L., Vaiman, D., and Miralles, F. Oxidative Stress in Preeclampsia and Placental Diseases. Molecular Science. Int J Mol Sci. 2018; 19(5):

1496.doi; https://dx.doi.org/10.3390\%2Fijms190514 96.

11. Chaiworapongsa, T. Pre-eclampsia part 1: Current understanding of its pathophysiology. Research Gate PMC. 2018; 1-37.

12. Astutik, P. Adriani, M. \&Wirjatmadi, B. Kadar RadikalSuperoksid (O2-), Nitric Oxide (NO) dan Asupan Lemak Pada PasienHipertensi dan TidakHipertensi. JurnalGizi Indonesia Universitas Airlangga, Indonesia. 2015;3(1);18584942

13. Beg, M. Sharma, V. Akhtar, N. Gupta, A \&Mohd, J. Role of Antioxidants in Hypertension. JIACM. 2011;12(2);122-7.

14. Darwin E, Elfi EF, Elvira D. Endotel Fungsi dan Disfungsi. Andalas University Press : Padang. 2017.

15. Guerby.P, Tasta. O, Swiader. A, a , Pont. F, Bujold. E , et al. Role of oxidative stress in the dysfunction of the placental endothelial nitric oxide synthase in preeclampsia. 2021;2213-2317. https://doi.org/10.1016/j.redox.2021.1018 61.p1-9.

16. Parwata, M.O.A. Bahan Ajar Uji Bioaktivitas :Antioksidan. Universitas Udayana. 2016;1-54

17. Phipps, E. Prasanna, D. Brima, W \& Jim, B. Preeclampsia: Updates In Pathogenesis, Definitions, And Guidelines.NewYork. Clin J Am Soc Nephrol 11: 1102-1113, 2016. doi: 10.2215/CJN.12081115.

18. Abdou, H.M. Mohamed, N.A. Mekkawy, D.A.E \& El-Hengary, S.B. Vitamin E And Or Wheat Germ Oil Supplementation Ameliorate Oxidative Stress Induced By Cadnium Chloride In Pregnant Rats And Their Fetuses. Jordan Journal of Biological Sciences. 2017; vol. 10, no. 1. pp. 39-48.

19. Fu Zhu-mei . Ma Zhen-zhi. Liu Guo-jie L. Lan-ling Wang \& Yong Guo. Vitamins Supplementation Affects The Onset Of Preeclampsia. Journal of Formosan Medical Association 2018 (117); 6- 
13.https://doi.org/10.1016/j.jfma.2017.08. 005

20. Lalenoh, C.D. Preeklampsia dan Eklampsia .Yogyakarta : CV Budi Utama. 2018;12-17.

21. Matsubara, K. Higaki, T. Matsubara, Y \&Nawa, A. Nitrit Oxide and Reactive Oxygen Species in the Phatogenesis of Preeclampsia. Int. J. Mol. Sci. 2015,16, 4600-4614; doi;10.3390/ijms16034600.

22. Rusiani, E. Junaidi, S. Subiyano, H.S \&Sumartiningsih, S. Suplementasi Vitamin C dan E untukMenurunkan Stres Oksidatif Setelah Melakukan Aktivitas FisikMaksimal. Media IlmuKeolahragaan Indonesia Vol 9. No. 2. p-ISSN 20886802 . e-ISSN 2442-6830.2019.

23. Tripathi, N. Singh, A. Pandey, K, Singh, $\mathrm{N} \&$ \& Arya, S. Role Of Anti-Oxidant To Reduce Free Radical Induced Injury In Preeclampsia. Int $\mathrm{J}$ Reprod Contracept Obstet Gynecol. 2016;Nov;5(11):37953798.doi

http://dx.doi.org/10.18203/23201770.ijrcog20163841.

24. Bakouei , F. Delavar, M.A,. Amiri, S.M. Esmailzadeh, S \& Taheri, Z. Efficacy Of N-3 Fatty Acids Supplementation On The Prevention Of Pregnancy InducedHypertension Or Preeclampsia: A Systematic Review And Meta-Analysis. Taiwanese Journal of Obstetric and Gynecology 59(2020);8-15 .https://doi.org/10.1016/j.tjog.2019.11.002

25. Burchakov, D.I. Kuznetsova, I.V \&Uspenkaya, Y.B. Omega-3 Long Chain Polyunsaturated Fatty cids and Preeclampsia : Trials say "No" but is it the final word?. Nutrients.2017;9(12). doi:10.3390/nu9121364.

26. Kemse, N., Kale, A., and Joshi, S. (2014). A Combined Supplementation of Omega3 Fatty Acids and Micronutrients (Folic Acid, Vitamin B12) Reduces Oxidative Stress Markers in a Rat Model of Pregnancy Induced Hypertension. PLoS ONE 9(11);e111902. 2014. Doi;10.1371/journal.pone.0111902

27. Kemse, N., Kale, A., and Joshi, S. Supplementation of maternal omega-3 fatty acids to pregnancy induced hypertension Wistar rats improves IL10 and VEGF levels. Elsevier. Prostaglandins Leukot Essent Fatty Acids. 2016;104:2532.doi: 10.1016/j.plefa.2015.11.003.

28. Utami, C. T. Berawai, K.N \& Karima, N. HubunganSuplementasi Omega-3 pada Ibu HamildenganKejadianPreeklampsia. Journal FakultasKedokteran Universitas Lampung. 2018; Vol. 7 no. 3.

29. Smith G, Atherton P, Reeds D, et al. Dietary omega-3 fatty acid supplementation increases the rate of muscle protein synthesis in older adults: a randomized controlled trial. American Society for nutrition. Am J Clin Nutr. 2011;93:402-12. doi: 10.3945/ajcn.110.005611.

30. Vijayalakshmi, B. Ambarhesa, K. Kayalvizhi, E. Qairunnisa, S. Revathi, M, \& Chandrasekhar, M.. Effect OfAntioksidan in Preeclampsia Women at Increased Risk. Int J Med Res Health Sci. 2013;2(2);177-181.

31. Kasture, V., Kale, A., Randhir, K., Sundrani, D., and Joshi, S. Effect of maternal omega-3 fatty acids and vitamin E supplementation on placental apoptotic markers in rat model of early and late onset preeclampsia. Elsevier, 1-26. https:/doi.org/10.1016/j.lfs.2019.117038

32. Aldosari, S. Awad, M. Harrington, E.O, Selke, F.W. \& Abid, M.R. (2018). Subcellular Reactive Oxygen Species (ROS) in CardiovaskulerPhatofisiology. Antioxidants. Vol. 7. Issue.14., doi: 10.3390/antiox7010014.

33. Cardoso, P., and Surve, S. The Effect of Vitamin $\mathrm{E}$ and Vitamin $\mathrm{C}$ on the Prevention of Preeclampsia and Newborn Outcome: A Case-Control Study. The Journal of Obstetrics and Gynecology of India.2016; 66(S1):S271-S278. DOI 10.1007/ s13224-016-0885- 2016;271278.

34. Magenta, A., Greco, S., Capogrossi, M.C., Gaetano, C. and Martelli, F. Nitric Oxide, Oxidative stress, and interplay in diabetic endothelial dysfunction. Biomed research international. 2014

35. Basu. A \&Lyions, T. Antioxidans, stress oxidative, and preeclampsia on diabetes . 2020;152-157.

DOI: 
Dina Taufia et.al. The effect of administration of omega-3 and vitamin $e$ on the levels of reactive oxygen species (ROS) and nitric oxide (NO) in preeclampsia white rats (rattus norvegicus).

https://doi.org/10.1016/B978-0-12-

815776-3.00015-2

36. Förstermann, U. Sessa, WC. Nitric Oxide Synthases: Regulation And Function. European Heart Journal (2012) 33, 829837. doi:10.1093/eurheartj/ehr304.

37. Middleton P, Gomersall J.C, Gould J.F, Shepherd E, Olsen S.F\&Makrides M. .Supplementation Omega-3 Fatty Acid During Pregnancy. Cochrane Database of Systematic Review. Cochrane Database Syst Rev .2018 Nov 15;11(11): CD003402. doi: 10.1002/14651858.CD003402.pub3.

38. Sepridarkish, M \&Fakhrabadi, M.A. Effect of Omega-3 fatty acid plus vitamin E Co-supplementation on oxidative stress parameters ; a systematic review and meta-analysis. Clinical Nutrition. 2019. doi; 10.1016/j.clnu.2019.05.004.

39. Sutton, E. Gemmel, M. Powers,R.W. Nitric oxide signaling in pregnancy and preeclampsia.2019.doi;

https://doi.org/10.1016/j.niox.2019.11.006 .pp 1-16

How to cite this article: Taufia D, Muhammad $\mathrm{S}$, Amir A. The effect of administration of omega-3 and vitamin e on the levels of reactive oxygen species (ROS) and nitric oxide (NO) in preeclampsia white rats (rattus norvegicus). International Journal of Research and Review. 2021; 8(12): 7-15. DOI: https://doi.org/10.52403/ijrr.20211202 